\title{
The Actor's Attitudes Towards the Principles of Governance: The Case of Maritime Commerce Sector in Turkey
}

\author{
Fatih Turan YAMAN* \\ Emrah YAMAN**
}

\begin{abstract}
This paper asserts that the question about how such a complex, diverse and dynamic sector as maritime commerce can be directed and coordinated in Turkey gives a rise to the idea of governance which is more sensitive to the demands and interests of stakeholders. It also argues that the way to the governance mechanisms that have to be established in the maritime commerce sector is furnished with the concrete governance principles to a large extent. Within this framework the aim of this paper is to analyse actor's attitudes towards governance principles in the Turkish maritime commerce sector. In the empirical part, the attitudes of the executives of the institutions and organizations operating in the Turkish maritime commerce sector towards the governance process in theory and in practice are examined with the help of a questionnaire named as "interorganizational governance scale." This discussion, along with empirical evidence provided by executives of public, private and third sectors, leads to the conclusion that tangible governance mechanisms should be established for proper implementation of the principles of governance.
\end{abstract}

Keywords: Governance, Governance principles, Maritime commerce sector, Policy-making, Interorganizational governance.

\section{Aktörün Yönetişim İlkelerine Yönelik Tavırları: Türkiye’de Deniz Ticareti Sektörü Örnek Olayı}

\section{Özet}

Bu makale deniz ticareti gibi karmaşık, çeşitli ve dinamik bir sektörün Türkiye'de nasıl yönetileceği ve koordine edilebileceği sorusunun paydaşların istek ve beklentilerine daha duyarlı yönetişim

\footnotetext{
* Dr. Fatih Turan Yaman (Ph.D), Head of Management and Organization Department, İstanbul Aydın University Anadolu BIL Vocational School of Higher Education. Email: yamanft@hotmail.com

** Dr. Emrah Yaman (Ph.D), Maritime Expert on International Affairs, Republic of Turkey Ministry for Transport, Maritime Affairs and Communication. Email: yamanemrah34@gmail.com
} 
düşüncesini ortaya çıkardığını iddia etmektedir. Makale aynı zamanda deniz ticareti sektöründe kurulması gereken yönetişim mekanizmalarına giden yolun büyük ölçüde somut yönetişim ilkeleri ile döşendiğini ileri sürmektedir. Bu bağlamda bu çalışmanın amacı Türk deniz ticareti sektöründeki aktörlerin yönetişim ilkelerine yönelik tutumlarını analiz etmektir. Ampirik bölümde Türk deniz ticaretinde faaliyet gösteren kurum ve kuruluşlardaki üst düzey yöneticilerin teori ve pratikte yönetişim sürecine karşı tutumları "kurumlararası yönetişim ölçeği” adlı anket formuyla incelenmiştir. Kamu, özel ve üçüncü sektör yöneticilerinden elde edilen ampirik kanıtlarla birlikte söz konusu tartışma, yönetişim ilkelerinin tam uygulanabilmesi için somut yönetişim mekanizmalarının kurulması gerektiği sonucuna ulaşmıştır.

Anahtar kelimeler: Yönetişim, Yönetişim ilkeleri, Deniz ticareti sektörü, Politika oluşturma, Kurumlararası yönetişim.

\section{Introduction}

Governing systems of today's world are going under a rapid transformation. Instead of existing and traditional static models of decision-making and policy formulation characterized by their hierarchical structure, a new governing model defined as participative and partnershipbased with multiple actors has come to the forefront. The concept of governing leaves its throne to the idea of governance. There is order in the decision-making and policy formulation area as usual but nowadays it is not imposed from on high; it emerges from the negotiations of several relevant parties. Public, private and non-governmental actors in a particular policy area need one another. Because no one has all the relevant knowledge and resources to make the policy work.

Policy-making in maritime commerce sector continues to be formulated within a traditional nested hierarchy of jurisdictions that pays little attention to new relationships that exist and intensify between relevant parties. Nevertheless, struggles for establishing effective, flexible, transparent, cooperative, equitable, accountable, participative structures instead of ponderous, bureaucratic and compelling administrative structures give a rise to the pronunciation of governance and governance principles more frequently in the maritime sector as well. Because the failure of the political mechanisms to accept the requirement for governance framework and proper implementation of governance principles continues to cause policy deficiencies and problematic maritime commerce policies which reflect these deficiencies.

Without a doubt, Turkish maritime commerce sector gets its share from these developments. Turkish maritime commerce sector exhibits significant failures of policy, stemming from a governing framework built around a static nested hierarchy which contradicts the real-life situation and the needs and desires of maritime stakeholders.

Maritime commerce sector needs governance mechanisms that are appropriate for a globalised industry working across all jurisdictions in a complex environment. However, literature on governance issues in Turkish maritime sector is still missing in terms of quality and 
quantity. In this respect this paper tries to bridge the gap among research, policy and practice on maritime commerce sector and governance issues. This paper also examines these issues drawing themes from theoretical studies of governance and interrogating the implementation level of governance principles in the practical context of Turkish maritime sector through formulating a questionnaire named as "interorganizational governance scale. The questionnaire comprising 19 items to determine the attitudes of the executives towards governance principles in a specific sector as attributable to the area of maritime commerce is original in that sense. This may be an ambitious task in the limited space available but it is hoped that the suggestions offered in the paper can at least be drawn out to further debates and researches addressing the effectiveness of internal corporate governance mechanisms as they apply to the maritime industry in Turkey.

This paper is organised in the following way. The following section reviews the literature on the concept of governance, which is pronounced as a new governing perception, the principles of governance and points out the significance of governance mechanisms in the maritime commerce sector. The fundamental hypothesis developed in the empirical part is that public sector pays little attention to the demands and interests of relevant parties and a significant difference exists regarding the implementation level of governance principles among the organizations in Turkish maritime sector. Details of field research are discussed in the empirical section and findings on the attitudes of the executives in Turkish maritime commerce sector to the principles of governance and the implementation level of the principles are presented in the penultimate section. A concluding remark is given in the last section.

\section{The Concept of Governance}

Governance refers to a more comprehensive term pointing out the distribution of authority, although sometimes considered synonymous with governing. As Andrew Taylor (2002:37) stated, "Whilst governance occurs without government, government cannot happen without governance." In the words of Stoker (1998:1), it is "direct[ing] attention to the distribution of power both internal and external to the state".

Governance means many different things to many different people. In the literature, it is "popular but imprecise" (Rhodes, 1996: 652) and it is "such a short and a simple word but what confusion it causes" (Roe, 2013: 41). Some authors define governance in general terms. For instance, Kooiman (1993) considers governance as the patterns that emerged from governing activities of social, political and administrative actors, whereas Jessop (1998) describes it as any mode of coordination of interdependent activities or as heterarchy (or self-organization). In wondering whether governance has a distinct meaning, there are six uses of the term for Rhodes (1996): the minimal state, corporate governance, the new public management, good governance, sociocybernetic systems, and self-organizing networks, while focusing on "self-organizing, interorganizational networks" as his preferred meaning.

Changing focus from government to governance is one of the most significant developments in the field of public administration. Tokoz (2008: 5) defines governance as "political, economic 
and administrative power that societies use to administer their activities." Kooiman (2003) defines the term of governance as a body of interactions that sets its sight on resolving disputes between the actors from public, private and non-governmental sectors, creating social opportunities and that participates in the organizations which provide resource for this interaction and establishes a normative basic structure for all actions. Kooiman (2003:4) points out that governance is "the totality of theoretical conceptions of governing."

In the same vein, contrary to governing, which is imposing, based on hierarchical relations and targeted to the implementation of scheduled works, considering the fact that governance comprises voluntary organizations, it is a broader cooperation and harmonization process based on the horizontal relations (Fitzpatrick and Sohal, 2002). Cooperation is taken up by Menteş (2009: 71) as well, who argues that governance is "a structure or system which is formed by collective harmonized efforts of related agents in a socio-political order." On the other hand, Borzel (2010) suggests that governance has to consist of both structure and process, the former consisting of the actors and institutions and the latter the social coordination that takes place between them. Pierre sums up different views on governance in the following definition (2000:3): "Governance refers to sustaining coordination and coherence among a wide variety of actors with different purposes and objectives such as political actors and institutions, corporate interests, civil society, and transnational organizations."

Pierre (2000) also considers the governance as the adaptation of the government to the evolving external environment, as an interaction framework between the social systems and as the role of the government in this process. Peters (2000) further distinguishes two more concepts within the second meaning - "state-centric" and "society-centric" concepts, with the first one referring to the political and institutional capacity of the state to govern, and the second one - to forms of public-private interaction. Williams (2005) also provides a state-oriented definition by focusing on the capacity of the state to govern social, political and economic processes.

Hirst (2000) enriches the governance debate by proposing the following five modes of governance.

1. Good governance refers to the establishment of efficient political framework favourable to enhancement of economic development - stability, rule of law, transparent public administration, accountability and responsibility of state actors and a strong civil society.

2. Globalgovernance denotes patterns of cooperation among states and international institutions in addressing world-wide challenges such as environmental problems, regulation of global trade, threats to international peace and security. Some scholars (Rosenau, 1992) consider the term as "governing without government".

3. Corporate governance refers to the system of direction and control of organizations. It also refers to the framework of rules and practices by which a board of directors ensures accountability, fairness and transparency in a company's relationship with its all stakeholders. (customers, management, government, employees and the community) 
4. New public management (NPM) refers to governance in two important aspects of the public sector - privatization of publicly owned industries and public services and introduction of commercial practices and management patterns within the public sector.

5. Networks, is about coordinating and channelling activities via networks and various forms of partnerships. Literature identifies networks of public structures, private entities and combinations of those two types of organizations. Networks are defined as "pluri-centric forms of governance" as compared to "multi-centric" (market) and "unicentric" (state) forms (Rhodes, 2000).

For the purpose of the paper, networks and corporate governance modes deserve a particular emphasis as they provide the possibility of treating governance not only as tied to the issues of general policy-making but in light of a specific sector-approach, as attributable to the area of maritime commerce sector. Maritime stakeholders range from international institutions and business circles to NGOs and civil society and act in the context of permanent negotiation and bargaining. They act within networks where hierarchy is gradually replaced by cooperative and collaborative arrangements.

On the other hand, there is a growing apprehension of the fact that our societies are becoming increasingly fragmented, complex and dynamic. However, Turke (2008) regards complexity, diversity and dynamics as core features of today's governance referring to the fact that modern societies are multilayered and complicated and that multiple actors rather than governments alone, feature prominently. These actors are pluralist and fragmented and governments switch between representation of local/regional to international/supranational constituencies at alarming speed. The reliance on interactive mechanisms and strategies that would help solve emerging problems and benefit from opportunities is therefore obvious. Policy networks are referred to as networks of actors such as representatives of government, business, civil society, interest groups involved in public governance (Torfing, 2005).

Governance networks distinguish themselves from the hierarchical control of the state and the competitive regulation of the market through suggesting a redistribution of power through a network of actors. In terms of relations between actors, governance networks involve a large number of interdependent and yet autonomous actors who interact over time to produce public purpose (Klijn, 2008). In terms of decision-making, governance networks make decisions and regulate issues through "reflexive interaction" among many actors (Torfing, 2005). Lastly, confidence and sense of common ownership maintained by self-continued regulations within these networks ensure compliance with jointly agreed upon options (Kjaer, 2004).

In broad terms, corporate governance refers to the way in which a corporation is directed, administered, and controlled. It covers economic and political processes that shape the role of various actors in the context of governance. Corporate governance also concerns the relationships among the various internal and external stakeholders involved as well as the governance processes designed to help a corporation achieve its goals (Baker and Anderson, 2010).

Corporate governance is concerned with holding the balance between economic and social 
goals and between individual and communal goals. The corporate governance framework is there to encourage the efficient use of resources and equally to require accountability for the stewardship of those resources. From this point of view corporate governance identifies three basic principles which could be applied equally to maritime organizations operating in the public, private and third sectors: openness or disclosure of information; integrity or straightforward dealing and completeness; and accountability or holding individuals responsible for their actions by a clear allocation of responsibilities and clearly defined roles.

Although a narrow use of the concept, the concerns of corporate governance are echoed when discussing accountability and responsiveness in the new public management and good governance principles. As Rhodes (1996: 654) states explicitly that "this use reminds us that private sector management has an important influence on the public sector."

In sum, governance refers to a new governing process; or to the evolving condition of regular rules; or to a change in the definition of the governing addressing to the society's being governed by new methods (Rhodes, 1996). According to Stoker (1998), the world of governing is exposed to dramatic changes and portrays a substantial break from the past and this changing world is worth of study.

It is apparent that the process, which gives a rise to the usage of the concept of governance for the description of the evolution in governing, makes governance to be conceptualized more difficult. However, if it is necessary to make a short definition of the concept, governance, a condition of the public sector's being equal relatively with private sector and civil society, means co-regulation, co-production and co-management. In other words, governance represents a complex system containing public administration, private sector and civil society. These actors, who have to be in mutual interaction and have specific roles on their own part, are organizations of public sector, private sector and civil society.

\section{Governance in Maritime Commerce}

Governance is a complex and ever changing concept that both reflects and is reflected by societal change. Nowadays the failure of policy formulation and decision-making mechanisms to recognize the need for a sensitive and flexible governance framework leads to policy inadequacy and failure. Problems in maritime commerce sector may be reflection of such inadequacies (Roe, 2013).

Regarding the sector of maritime commerce, cooperation and partnership mechanisms to be established between stakeholders in the context of governance are potentially of great importance. This is because the government provides service in a very restricted area in maritime commerce sector, but nonetheless enterprises are the primary actors bearing the burdens of the sector. Furthermore, a wide range of non-governmental organizations (NGOs) operating for resolution of disputes in the sector also exist. Consequently, it is very difficult for public administration, which excludes other actors during decision making and policy setting processes, to succeed in maritime commerce sector. 
As being one of the most important international sectors (Stopford, 1997), maritime commerce sector is a sphere of activity that comprises such elements like vessels and the commercial lanes of the vessels, ports for loading and unloading and some certain maritime markets, which mean a commercial environment for vessels and freights. Services are typically provided worldwide, ownership is commonly highly cross-national, and employment is fairly global (Randøy et al., 2003). All these sectoral activities such as ship building industry, ownership and operation of vessels, port and logistic services are conducted in a very competitive atmosphere that is shaped by international requirements (Kumar and Hoffmann, 2002). The administrations which survive in this competitive atmosphere are the ones which are not directed by political concerns, which can implement contemporary governing techniques and which has a decentralized and forward looking organizational structure.

The current process invites the states not only to establish vertical relations from top to bottom but also to take decisions and establish policies with civil NGOs and private sector enterprises at the horizontal level through policy networks. In this period of change, it becomes essential to reorganize and shape the role of the state in the society and the relations between the government, bureaucracy, enterprises in the sector and NGOs in a new framework. In other words, it is indispensable to make sovereign a steering public administration approach instead of a rowing one in the maritime commerce sector to achieve network governance and incorporating governance principles into their internal structure is prerequisite for all organizations operating in maritime commerce sector.

\section{The Principles of Governance}

The governance takes place just in the middle of the processes for establishing maritime commerce policies and decision making. Regarding this fact, it is clear that how complex the area is and how the negotiations (Roe, 2013) about establishing general policies in and out of the sector become significant. For example, negotiations ranging from multi-level governance (Hooghe and Marks, 2003; Bache and Flinders, 2004; Papadopoulos, 2005; Stubbs, 2005; Roe, 2007, 2013; Zielonka, 2007; Mamudu and Studlar, 2009; Shore, 2011) to poly-centric governance (Skelcher 2005; Roe 2009) point out the anticipated superstructure to be established regarding the governance in the maritime sector. However before starting to make an evaluation on the things to be done about this governance perception, it is important to put emphasis on the contemporary principles of governance, which constitutes the infrastructure of governance. Because although some positive inferences exist in academic studies, the value of the concept increases as the governance is a normative theory with definite principles. From this point of view, it is necessary to examine the principles of the governance which is used to express a complex system comprising private sector and NGOs and their relational network and mutual interactions. These principles, which are named as good governance principles summarizes the position of the World Bank and other international finance institutions and European Union (IMF, 1997; Commission of the European Communities, 2001; World Bank, 2000; OECD, 2005; Fritz, 2010). 
These principles are as follows:

1. Accountability: means decision-makers in government (elected or appointed) to be held responsible of their own acts and their being ready and willing to give account. In terms of the governance perception, accountability is understood to be used as a responsibility to report of the performance information related to how efficiently; effectively and economically the executives use the authority and resources allocated to them. This principle is valid not only for the public administration but also for private sector and NGOs and these organizations have to be accountable before the public and their own stakeholders.

2. Rule of law: means the enactment of laws, which ensure openness, predictability and stability for all sectors and making use of this system for the resolution of disputes.

3. Responsiveness: means the knowledge of the citizens that they will be listened and responded by the public officers. This principle is related to the government's being responsive to every kind of proposal, criticism, appreciation, complaint and development and being ready and willing for any type of evolution and interaction. The substructure of this is constituted by the information's being accurate and accessible about economic conditions, budgets and requirements of the markets and public. The submissions by the beneficiaries of the public services have to be considered during the decision making process. In this manner, by the help of the response provided for the citizen, the citizen feels him/herself as a part of governing and takes responsibility and the decisions taken in the light of the information provided will be more effective and efficient.

4. Openness and Transparency: mean a call for an open government, whose principles of openness and transparency enhances the accountability and who facilitates the intersectoral consultation processes. In other words, it means procurement of openness and transparency in every phase in order to ensure reliable flow of information whilst planning, determining targets, making decisions, implementing and evaluating without being monocentric and exclusivist. With the establishment of this principle, the government will break its own shells and be in an interaction with the other economic and social actors at every stage of decision making and policy setting processes.

5. Participation: sets a partnership and cooperation between public-private-voluntary organizations as an objective in the decision making and implementation processes related to public policies. In this manner, it becomes possible for the citizens to participate in the processes of decision making and policy setting directly or representatively. The consciousness of partnership for reconciliation and cooperation between different interests pave the way for democratic cooperation in governing.

6. Efficiency: means the success shown in coming to fruition and the set policies and made decisions' being effective and applicable. The concept of efficiency is evaluated with such criteria like producing results that meet needs while making the best use of resources, 
technical equipment, being aware of and sensitive to some certain concerns of the people, creating an atmosphere where these concerns can be expressed and searched for a solution.

7. Equality: means creating a level playing field and assigning rights and responsibilities at the same level to parties involved. The equality perception is composed of such principles like not granting privileges any part of the society related to the decisions to be taken and taken in the past by the public sector, setting up the rules openly and clearly and implementing those rules equally and the related actors' being equally effective not only in service delivery but also in the processes of decision making and policy setting.

8. Strategic Vision: Nowadays the governing activities should be conducted considering the possible prospective challenges and requirements as much as the present ones. Henceforth, a long term, large scale and comprehensible vision, which evolves and develops in a line taking into account the requirements and expectations of the related parties, should be valid. In that, as the other principles of governance are built on a long term, sustainable vision and a mission, strategic governing becomes more of an issue.

In these regards, governance is possible with the establishment of stability, rule of law, transparency, responsiveness, accountability and effective political framework that is suitable for increasing the economic development. Good economic governance also constitutes a part of "second generation of reforms" comprising the enhancement of public-private partnerships, investments in the education and investigation and optimization of the public expenditures (Rosenbaum and Shepherd, 2000). It is a reality that good governance comprises examples of best practices in regards of public administration, government-private sector relations and social policies in the industrialized countries as well (Kersbergen and Waarden, 2004).

The evolution in the social and economic systems transforms the governing by reorganizing the institutional relations in the government. Also in the maritime sector, mutual cooperative processes between public authorities and increasing organizations at the other platforms are being experienced. For the participation and contribution of the parties affected by decisions and policies directly or indirectly to all or one of the decision making and policy setting, a proper implementation of the principles of governance is condition sine qua non. At this juncture, expressing that the way to the governance mechanisms that has to be established in the maritime commerce sector will be furnished with the concrete governance principles to a large extent is a fact instead of being an assertion.

\section{A Field Research}

\section{The Purpose of Research}

The scope of the research is to evaluate the attitudes of the executives of the institutions and organizations operating in the Turkish Maritime Commerce sector towards the governance 
process in theory and in practice. In the framework of this basic scope, whilst the attitudes of the executives to the principles of governance and the implementation level of the principles are tried to be determined, to what extent governance is implemented in the maritime commerce sector is examined.

\section{The Population and Sample in the Research}

The population of the research is the public institutions and organizations, private sector enterprises and NGOs operating directly or indirectly in the sector. The research was conducted with the executives who are thought to be efficient regarding governance. These executives comprise undersecretaries, deputy undersecretaries, general directors, deputy general directors, chairmen of the board of governors or vice chairmen, general secretaries, deputy general secretaries, members of board of governors, head of departments and harbour masters who are the representatives of the organizations operating in the sector.

46 public institutions and organizations operating directly or indirectly in maritime commerce sector exist in Turkey. During the research, all public authorities in the universe were contacted and necessary data were collected. In a similar way, 42 NGOs operate in the maritime commerce sector in Turkey and all the known units in the universe were surveyed.

Instead of the universe, data acquisition by an evaluation on smaller group representing universe has been valid for the private sector enterprises. Istanbul \& Marmara, Aegean, Mediterranean, Black Sea Regions Chamber of Shipping (IMEAK Chamber of Shipping) was chosen to analyse in the private sector. By the year of 2013, 8275 active members are registered to IMEAK Chamber of Shipping and 4590 of those are operating in Istanbul province. The sampling frame was accepted as the universe, however considering the challenges to be encountered to access all the respondents, in total 284 private sector enterprises that compose 47 professional committees and that are operating in the different fields of maritime commerce sector within the body of IMEAK Chamber of Shipping were accessed and necessary data was collected.

The centre of the Turkish maritime commerce is Istanbul province and these features became effective in the questionnaire's being limited with private sector enterprises operating in Istanbul other than enterprises in the professional committees to reach significant sample size. So, a sample size of 395 enterprises was reached for a population of 8275 enterprises received from the records of IMEAK Chamber of Shipping by means of purposeful (judgement) sampling (Deming, 1990; Marshall, 1996) in order to reach a significant sample size in the research which is limited with the private sector enterprises operating in Istanbul. The appropriate sample size was determined with the formula ( $\mathrm{n}=\mathrm{N} \cdot \mathrm{t}^{2} . \mathrm{p} . \mathrm{q} / \mathrm{d}^{2}(\mathrm{~N}-1)+\mathrm{t}^{2}$.p.q) which is used when the size of population is known in accordance with 95\% confidence level (Balc1, 2006; Baş, 2008). In this formula, $\mathrm{N}$ symbolises the number of establishments in the population, $\mathrm{n}$ symbolises the number of establishments for sampling, p symbolises the frequency of the analysed case (probability of occurrence) (0.50), q symbolises the frequency of the time in which the analysed case is not observed (probability 
of non-occurrence) (0.50), $\mathrm{t}$ symbolises the theoretical value calculated in accordance with $\mathrm{t}$ table at a certain significance level, $d$ symbolises the deviation \pm accepted in accordance with the occurrence frequency of the case (0.05).

Accordingly, for a population consisting of 8275 enterprises, a sample size of 368 enterprises is required to generate a margin of error of $\pm 5 \%$ (Saunders, Lewis and Thornhill, 2003). Considering the fact that the sample size of the research is 395 enterprises, it can be understood that such a sample size would be enough comparing to 368 enterprises.

\section{Model of the Research}

The field study was structured on descriptive research design. The purpose of this descriptive research design is to figure, to describe and to clarify what a condition, a relation, an implemented policy and a problem is; to determine the valid variables and their mutual relations; to make comparisons and evaluations; to develop new alternative action choices and to set policies and make decisions by making use of the experiences gained.

Descriptive studies create a basic database about the features of the certain variables whilst dealing with the properties of the phenomenon (Sekaran, 2002; Creswell, 2013). The fact that the principles and rules about governance are not very conclusive in Turkey and scarcely any implementation about governance exists in Turkish maritime commerce sector give a rise to the preference of such a research model.

\section{Factor Analysis}

This research study, whose purpose is to determine the attitudes of the executives towards the principles of governance, is considered in the framework of three main factors. Initially, the factorability of the 19 items was examined.

Firstly, the Kaiser-Meyer-Olkin measure of sampling adequacy suggested that the sample was factorable $(\mathrm{KMO}=0.946)$ and Bartlett's test of sphericity was significant $\left(\mathrm{X}^{2}(171)=6811,357, p\right.$ $<0.001)$.

Secondly, the diagonals of the anti-image correlation matrix were all over .5, supporting the inclusion of each item in the factor analysis. Given these overall indicators, the analysis was yielded a three factor solution with all 19 items.

Finally, the initial eigen values showed that the first factor explained $23,284 \%$, the second factor $20,345 \%$, and a third factor $18,089 \%$ of the variance. Three components accounted for $61,718 \%$ of variance. Those factors are described as democratic cooperation in governing, the interaction level and efficiency of public sector and strategic governance, as shown in table 1. 
Table 1. Items of interorganizational governance scale

\begin{tabular}{|c|c|}
\hline Name of the Factor & Items \\
\hline $\begin{array}{l}\text { Democratic } \\
\text { Cooperation in } \\
\text { Governing }\end{array}$ & $\begin{array}{l}\text { - As regards providing input into the processes of agenda and policy setting in } \\
\text { maritime commerce sector, the economic and civil actors are effective at the } \\
\text { same level. } \\
\text { - The conveyed demands of the economic and civil actors have a significant impact } \\
\text { upon decisions taken and policies formed in terms of output process. } \\
\text { - Active participation, which means cooperation and partnership of all the } \\
\text { stakeholders in the processes of decision making and policy setting in maritime } \\
\text { commerce sector, is available. } \\
\text { - The public executives provide qualified and standardized service to meet the } \\
\text { expectations of the sectorial stakeholders. } \\
\text { - During legislative studies regarding maritime commerce the views and remarks } \\
\text { of the related public, private and social actors are considered. } \\
\text { - The public officers are attentive to the contribution of directly or indirectly } \\
\text { affected parties to the decision making processes related to public services. } \\
\text { - The public executives act consciously and responsively towards the concerns of } \\
\text { the stakeholders. } \\
\text { - The policy setting and decision making processes of maritime commerce are } \\
\text { conducted openly and transparently. } \\
\text { - The decisions of the administration related to maritime commerce are announced } \\
\text { to the stakeholders properly and periodically. }\end{array}$ \\
\hline $\begin{array}{l}\text { Strategic } \\
\text { Governance }\end{array}$ & $\begin{array}{l}\text { - The short, medium and long term objectives in the sector are determined } \\
\text { according to the strategic vision. } \\
\text { - The sector has a comprehensible strategic vision to enhance sustainable } \\
\text { development and competitive capacity. } \\
\text { - A strategic governing related to the basic priorities and objectives is concurringly } \\
\text { implemented in the sector. } \\
\text { - The strategic vision of the public sector and the strategic visions of the other } \\
\text { organizations and institutions operating in the maritime sector are in a harmony. }\end{array}$ \\
\hline $\begin{array}{l}\text { The Interaction } \\
\text { Level and } \\
\text { Efficiency of the } \\
\text { Public Sector }\end{array}$ & $\begin{array}{l}\text { - The documents and information requested from the public administrations are } \\
\text { shared with the demandants. } \\
\text { - The stakeholders of the sector are informed about the decisions taken by the } \\
\text { public administration related to their fields of activity as soon as possible. } \\
\text { - The public administration makes every effort to develop the maritime commerce } \\
\text { sector and to increase the international competitive capacity of the sector. } \\
\text { - The requirements and expectations conveyed to the public administration are } \\
\text { met and solved satisfactorily within the shortest time. } \\
\text { - The public administration provides the necessary coordination between all the } \\
\text { stakeholders of the sector to enable accurate investments. } \\
\text { - The public administration acts efficiently and effectively to mobilize the resources } \\
\text { to required fields in the sector. }\end{array}$ \\
\hline
\end{tabular}




\section{Questionnaire Development}

A questionnaire comprising 19 items to determine the attitudes of the executives towards the principles of the governance was used in the research. The questionnaire was named as "interorganizational governance scale" and all items were developed by the researchers. The items were organized in accordance with five-point Likert agree/disagree scale (1: Totally disagree, 2: Disagree, 3: Neither agree nor disagree, 4: Agree, 5: Totally agree).

The research was conducted with 613 executives in total from public authorities, private sector enterprises and NGOs between the dates of 15 June-12 August 2013. The answering ratio of the questionnaire conducted with accompaniment of the researcher is $100 \%$. No missing value came to the existence.

\section{Reliability Analysis}

The propositions, whose classification types were finalized by factor analysis in the research, were exposed to reliability analysis (Cronbach, 1990) after being classified in accordance with the received results. Internal consistency measured with Cronbach's alpha ranges between 0.85 and 0.89 , as seen in table 2 .

Table 2. Cronbach's coefficient alpha for variables

\begin{tabular}{lcc}
\hline Name of the Variable & No. of Propositions & Reliability Coefficient \\
\hline $\begin{array}{l}\text { Democratic Cooperation in Governing } \\
\text { The Interaction Level and Efficiency of } \\
\text { the Public Sector }\end{array}$ & 9 & 0.898 \\
Strategic Governance & 6 & 0.853 \\
\hline
\end{tabular}

\section{Testing For Normality of the Distribution}

The normality distribution of the remarks related to the dimensions of inter-organizational governance scale was analysed Kolmogorov-Smirnov test by the help of 15.0 version of SPSS program. The results of the test are as below in the table 3.

Table 3. Normality of the distribution

\begin{tabular}{lc}
\hline Kolmogorov-Smirnov Test & Interorganizational Governance Scale \\
\hline $\mathbf{N}$ & 613 \\
Kolmogorov-Smirnov Z & 1.845 \\
Asymp. Sig. (2-tailed) & 0.002 \\
\hline
\end{tabular}

According to the test results, the analyses were made by non-parametric techniques. $(\mathrm{p}<0.05)$ 


\section{Research Hypotheses}

With the objective to evaluate the relations of the variables, 3 hypotheses in total were developed. The hypotheses of the research were developed in the framework of the theoretical relations discussed before and as a result of the evaluations made by the help of the questionnaire and Kruskal Wallis analysis was implemented, as seen in table 4.

Table 4. Non-parametric Kruskal Wallis test

\begin{tabular}{|c|c|c|c|c|c|c|}
\hline Dimensions & Groups & $N$ & $\begin{array}{l}\text { Mean } \\
\text { Rank }\end{array}$ & $\begin{array}{c}\text { Chi- } \\
\text { Squared }\end{array}$ & $d f$ & $\begin{array}{c}p \\
\text { Value }\end{array}$ \\
\hline \multirow{4}{*}{$\begin{array}{l}\text { Democratic } \\
\text { Cooperation in } \\
\text { Governing }\end{array}$} & Public Institutions/Organizations & 109 & 466.96 & \multirow{4}{*}{125.267} & \multirow{4}{*}{2} & \multirow{4}{*}{0.000} \\
\hline & Private Sector Enterprises & 395 & 289.42 & & & \\
\hline & NGOs & 109 & 210.76 & & & \\
\hline & Total & 613 & & & & \\
\hline \multirow{4}{*}{$\begin{array}{l}\text { The Interaction } \\
\text { Level and } \\
\text { Efficiency of the } \\
\text { Public Sector }\end{array}$} & Public Institutions/Organizations & 109 & 469.53 & \multirow{4}{*}{113.546} & \multirow{4}{*}{2} & \multirow{4}{*}{0.000} \\
\hline & Private Sector Enterprises & 395 & 276.70 & & & \\
\hline & NGOs & 109 & 254.28 & & & \\
\hline & Total & 613 & & & & \\
\hline \multirow{4}{*}{$\begin{array}{l}\text { Strategic } \\
\text { Governance }\end{array}$} & Public Institutions/Organizations & 109 & 428.43 & \multirow{4}{*}{69.438} & \multirow{4}{*}{2} & \multirow{4}{*}{0.000} \\
\hline & Private Sector Enterprises & 395 & 291.28 & & & \\
\hline & NGOs & 109 & 242.53 & & & \\
\hline & Total & 613 & & & & \\
\hline
\end{tabular}

Hypothesis 1: Among the classifications determined in accordance with the nature of the organization operating in Turkish Maritime Sector, a significant difference exists regarding the democratic cooperation in governing.

According to the Table 4, the dimension of democratic cooperation varies in compliance with the nature of the organization $(\bar{X}=466.96, \bar{X}=289.42, \bar{X}=210.76)$. As a result of the nonparametric Kruskal Wallis Test implemented to determine whether this difference is statistically significant, a meaningful difference exists between the groups at the level of $\mathrm{p}<0.05(\mathrm{p}=0.000$, $\left.\mathrm{X}^{2}=125.267\right)$. Hypothesis 1 is supported.

Hypothesis 2: Among the classifications determined in accordance with the nature of the organization operating in Turkish Maritime Sector, a significant difference exists regarding the interaction level and efficiency of the public sector.

According to the Table 4, the dimension of the interaction level and efficiency of the public sector varies in compliance with the nature of the organization $(\bar{X}=469.53, \bar{X}=276.70, \bar{X}$ 
=254.28). As a result of the non-parametric Kruskal Wallis Test implemented to determine whether this difference is statistically significant, a meaningful difference exists between the groups at the level of $\mathrm{p}<0.05$ ( $\left.\mathrm{p}=0.000, \mathrm{X}^{2}=113.546\right)$. Hypothesis 2 is supported.

Hypothesis 3: Among the classifications determined in accordance with the nature of the organization operating in Turkish Maritime Sector, a significant difference exists regarding the strategic governance.

As shown on the Table 4, strategic governance varies according to the nature of the organization $(\bar{X}=428.43, \bar{X}=291.28, \bar{X}=242.53)$. As a result of Kruskal Wallis Test implemented to determine whether this difference is statistically significant, a meaningful difference exists between the groups at the level of $\mathrm{p}<0.05\left(\mathrm{p}=0.000, \mathrm{X}^{2}=69.438\right)$. Hypothesis 3 is supported.

\section{Findings}

The public executives' being responsive and conscious of the concerns of related actors and taking the remarks and views of the stakeholders into consideration and the cooperation and partnership mechanisms' being valid for policy setting and decision making are related to the meeting of the principle of participation which is one of the pillar of democratic cooperation. At this juncture, it can be stated that in contradiction with the public executives, the executives of the private enterprises and NGOs exhibit a negative attitude.

The open and transparent conduct of the processes of decision making and policy setting and the administration's announcing its own decisions to the stakeholders accurately and periodically are related to the meeting of the principle of openness and transparency which is another one of the pillar of democratic cooperation. It can be stated that, in contrast with the public executives, the executives of the private enterprises and NGOs have adverse opinions in terms of meeting the principle of openness and transparency.

In Turkish maritime commerce sector, the public executives' providing qualified and standardized service to fulfil the expectations and economic and civil actors' taking part in the processes of decision making and policy setting at the same level are related to the implementation of equality principle composing democratic cooperation in governing. Regarding the implementation of the equality principle, in contrast with the public executives, the executives of the private sector enterprises and NGOs may be said to exhibit negative attitude.

The sharing of the documents and information requested from the administration and transmission of administrative decisions about the activity fields of the stakeholders in a shortest time are related to the principle of responsiveness which determine the interaction level of the public. It can be asserted that validity of this principle in practice is generally accepted by executives of the public authorities, private sector and NGOs. However concerning the conveyed requirements' and expectations' being answered and solved satisfactorily within the shortest 
time, the executives of the private sector and NGOs exhibit negative attitude contrary to the public executives.

The administration's mobilizing the resources to the required fields efficiently and effectively in coordination and interaction with the other stakeholders and making every effort to develop the sector and enhance its competitive power are related to the efficiency of the public sector. At this juncture, as opposed to the public executives, the executives of the private sector and NGOs can be said to exhibit negative attitude regarding the validity of efficiency principle in practice.

The determination of the short, medium and long term objectives by common accord and the sector's having a clear strategic vision to enhance sustainable development and competitive capacity are related to the strategic governance. From this viewpoint, in contrast with the public executives, the executives of the private sector and NGOs can be said to exhibit negative attitude. On the other hand, the fact that all the strategic visions of the institutions and organizations operating in the sector are not in harmony is accepted by all respondents.

\section{Conclusion}

In this paper, good governance was included as a normative concept besides positive descriptions of governance concept. The components of the governance were also constituted by the combination of the characteristics of the good governance. Openness and transparency in the processes of decision making and policy setting; democratic structure based on cooperation in governing, in which the principles of participation and equality prevail; effective and efficient decision making and implementation of these decisions by interacting actors and having an understandable strategic vision constitute the basics of good governance. The findings obtained in field study indicate that regarding the fulfilment of governance principles an intersectoral rupture exists in theory and in practice and in contradiction with the executives of the public sector, the executives of the private sector and NGOs expose negative attitude.

The question about how such a complex, diverse and dynamic sector as maritime commerce can be directed and coordinated gives a rise to the idea of governance networks. From this point of view, tangible governance mechanisms should be established in order to reach the objectives of establishing an institutional basis to enhance the coordination between the actors, building an efficient policy circulation, ensuring efficient use of resources, auditing the implementations actively, developing an efficient and effective decision-making mechanism considering the interests of actors involved.

The tangible governance mechanisms to be established in maritime commerce sector can provide a positive opportunity environment for reflecting the actual activities within the sector and the priorities of the stakeholders involved and ensuring the principles of governance to be put into practice. In this respect, the synergy created with partnership and collaboration mechanisms may motivate the resources of private sector and NGOs that are not used adequately (capital, labour force, governing capacity or experience etc.). These resources integrated with 
the inputs of the public sector may result in more effective outputs than the ones succeeded by individual actors.

Creating an atmosphere, where the private enterprises and non-governmental organizations in the maritime commerce sector can come together with the maritime administration in national and international levels, increases the functionality of the system. Organizing meetings at regular intervals to determine the problems together in a result-oriented manner, negotiating the problems and developing a common sense and by this way achievement of the all processes' being monitored and controlled will be beneficial to foresee the potential problems and to take precautions against them.

Nevertheless, if the public administration share the decision making and policy setting processes with other related sectors by putting the principles of openness, participation and equality into practice, the effectiveness of governing comes true in the light of democratic cooperation and strategic objectives. In this respect, the task of the maritime administration is to formulize a mechanism to facilitate the participation of the stakeholders to achieve the objectives and targets. In order to achieve this, instead of focusing on governmental organizations and internal processes, the intersectoral processes that form a big share of policies about maritime commerce must be focused on. On the other hand, unless a clear leadership and will exposed by the public administration for interaction with other sectors exist, it is a crystal-clear fact that there will be no progress.

The real factors that will compel public bodies to change shall be the economic and social demands peculiar to the new governance perception. It is difficult for a change agenda with inadequate demands and expectations to be successful at the desired level. Legislative regulations may sometimes fail to satisfy the actualization of the governance principles. Thereby, this new process shall be shaped by public, private and civil actors together. From this point forth, it should not be forgotten that the sincerity and sustainable success of these institutions and organizations, which have not put the principles of governance into practice through corporate governance in their internal structure before collaborating in the light of governance perception will be disputable. 


\section{References}

Bache, I. and Flinders, M. (2004) "Multi-Level Governance and the Study of British Politics And Goverment", Public Policy and Administration, 19(1), 31-52.

Baker, H. K. and Anderson, R. (2010) Corporate Governance: A Synthesis of Theory, Research and Practice, New York: John Wiley and Sons.

Balc1, A. (2006) Sosyal Bilimlerde Araştırma, Ankara: Pegem A Yayıncılık.

Baş, T. (2008) Anket: Anket Nasıl Hazırlanır? Anket Nasıl Uygulanır? Anket Nasıl Değerlendirilir?, Ankara: Seçkin Yayıncılık.

Borzel, T. A. (2010) "European Governance: Negotiation and Competition in the Shadow of Hierarchy", Journal of Common Market Studies, 48(2),191-219.

Commission of the European Communities (2001) European Governance. A White Paper. COM (2001) 428, Brussels: Commission of the European Communities.

Creswell, J. W. (2013) Research Design: Qualitative, Quantitative and Mixed Methods, Approaches, California: Sage Publications.

Cronbach, L. J. (1990) Essentials of Psychological Testing, New York: Harper Collins.

Deming, W. E. (1990) Sample Design in Business Research, New York: John Wiley and Sons.

Fitzpatrick, P. and Sohal, A. S. (2002) "IT Governance and Management in Large Australian Organisations", International Journal of Production Economics, 75(1-2), 97-112.

Fritz, J.S. (2010) "Towards A New Form of Governance in Science-Policy Relations in the European Maritime Policy", Marine Policy, 34(1), 1-6.

Hirst, P. (2000) "Democracy and Governance", in PIERRE, J. (ed.) Debating Governance: Authority, Steering and Democracy, New York: Oxford University Press.

Hooghe, L. and Marks, G. (2003) “Unravelling the Central State, But How? Types of Multi-level Governance”, American Political Science Review, 97(2), 233-243.

IMF (1997) Good Governance: The IMF's Role, Washington: IMF Publications.

Jessop, B. (1998) “The Rise of Governance and The Risks Of Failure: The Case of Economic Development”, International Social Science Journal, 50(155), 29-45.

Kersbergen, K. V. and Waarden, F. V. (2004) "Governance As A Bridge Between Disciplines: CrossDisciplinary Inspiration Regarding Shifts In Governance and Problems of Governability, Accountability and Legitimacy", European Journal of Political Research, 43(2), 143-171.

Kjaer, A.M. (2004) Governance, Madlen: Polity Press.

Kooiman, J. (1993) Modern Governance: New Government Society Interactions, London: Sage Publications.

Kooiman, J. (2003) Governing As Governance, London: Sage Publications.

Kumar, S. and Hoffman, J. (2002) "Globalization-The Maritime Nexus", in GRAMMENOS, C. TH. (ed.) The Handbook of Maritime Economics and Business, London: LLP.

Mamudu, H. M. and Studlar, D. T. (2009) "Multilevel Governance and Shared Sovereignty: European Union Member States and the FCTC”, Governance: An International Journal of Policy, Administration and Institutions, 22(1), 73-97.

Marshall, M. N. (1996) “Sampling for Qualitative Research”, Family Practice, 13(6), 522-525.

Menteş, H. (2009) Kurumsal Yönetişim ve Türkiye Analizi, İstanbul: Derin Yayınları.

OECD, (2005) Policy Brief, Public Sector Modernisation: Open Government, February.

Papadopoulos, Y. (2005) “Taking Stock of Multi-Level Governance”, European Political Science, 4(3), 316-327.

Peters, B. G. (2000) “Governance and Comparative Politics" in Pierre, J. (ed.) Debating Governance: Authority, Steering and Democracy, New York: Oxford University Press. 
Pierre, J. (2000) "Introduction: Understanding Governance", in Pierre, J. (ed.) Debating Governance: Authority, Steering and Democracy, New York: Oxford University Press.

Randøy, T., Down, J. and Jenssen, J. I. (2003) "Corporate Governance and Board Effectiveness in Maritime Firms", Maritime Economics and Logistics, 5, 40-54.

Rhodes, R. A. W. (1996) “The New Governance: Governing Without Government”, Political Studies, 44(4), 652- 667.

Rhodes, R. A. W. (2000) “Governance and Public Administration" in Pierre, J. (ed.) Debating Governance: Authority, Steering and Democracy, New York: Oxford University Press.

Roe, M. (2007) “Shipping Policy and Multi-Level Governance”, Maritime Economics and Logistics, 9, 84-103.

Roe, M. (2009) "Multi-level and Polycentric Governance: Effective Policymaking for Shipping", Maritime Policy and Management, 36(1), 39-56.

Roe, M. (2013) Maritime Governance and Policy-Making, London: Springer.

Rosenau, J. N. (1992) "Governance, Order and Change in World Politics", in Rosenau, J. N. and Czempiel, E. O. (eds.) Governance without Government: Order and Change in World Politics, Cambridge: Cambridge University Pres.

Rosenbaum, A. and Shepherd, A. (2000) "IASIA Symposium on Governance, Responsibility and Social Enhancement: Governance, Good Government and Poverty Reduction”, International Review of Administrative Sciences, 66(2), 269-284.

Saunders, M., Lewis, P. and Thornhill, A. (2003) Research Methods for Business Students, Sydney: Prentice Hall.

Sekaran, U. (2002) Research Methods for Business: A Skill-Building Approach, New York: John Wiley and Sons.

Shore, C. (2011) "European Governance or Governmentality? The European Commission and the Future of Democratic Government", European Law Journal, 17(3), 287-303.

Skelcher, C. (2005) "Jurisdictional Integrity, Polycentrism and the Design of Democratic Governance", Governance, 18(1), 89-110.

Stoker, G. (1998) “Governance as Theory: Five Propositions”, International Social Science Journal, 50(155), $17-28$.

Stopford, M. (1997) Maritime Economics, New York: Taylor and Francis Press.

Stubbs, P. (2005) "Stretching Concepts Too Far? Multi-Level Governance, Policy Transfer and the Politics of Scale in South-East Europe", Southeast European Politics, VI (2), 66-87.

Taylor, A. (2002) "Governance" in Blakeley, G. and Bryson, V. (eds.) Contemporary Political Concepts: A Critical Introduction, London: Pluto Press.

Tokoz, F. (2008) Good Governance: Improving Quality of Life, İstanbul: TESEV Publications.

Torfing, J. (2005) “Governance Network Theory: Towards A Second Generation”, European Political Science, 4(3), 305-315.

Turke, R. (2008) Governance. Systematic Foundation and Framework, Heidelberg: Physica-Verlag.

Williams, D. (2005) Good Governance and Global Governance. Political Studies Association Annual Conference, Leeds.

World Bank, (2000) Helping Countries Combat Corruption Program at the World Bank since 1997, Washington DC: World Bank Publication.

Zielonka, J. (2007) "Plurilateral Governance in the Enlarged European Union”, Journal of Common Market Studies, 45(1), 187-209. 
